\title{
E-ZDRAVSTVO - UNAPREĐENJE ZDRAVSTVENOGA SUSTAVA PRIMJENOM INFORMACIJSKE I KOMUNIKACIJSKE TEHNOLOGIJE
}

Rajko OSTOJIĆ

Medicinski fakultet, Zagreb

Vlatka BILAS, Sanja FRANC

Ekonomski fakultet, Zagreb

UDK: 614.2(497.5):004.738.5

Izvorni znanstveni rad

Primlieno: 10. 6. 2012.

U suvremenim uvjetima živlienja informacijska i komunikacijska tehnologija omogućuju brži i jednostavniii pristup zdravstvenoi zaštiti te prevladavanje jaza između prostorne i vremenske udaljenosti, čime je pružanje usluga uvelike pojednostavnjeno. Sve navedeno upućuje na velik potencijal e-zdravstva u budućnosti, štoviše, ono će postati imperativ modernoga društva. Kvalitetan, dobro organiziran i efikasan zdravstveni sustav koji potiče inovacije kao što je e-zdravstvo donosi koristi pojedincu, ali i čitavom društvu i ekonomiii. U radu se utvrđuju prednosti, nedostaci i zapreke praksi e-zdravstva u zemljama članicama Europske unije i u Hrvatskoj, a s obzirom na potencijal koji e-zdravstvo ima i može imati u unapređenju sustava zdravstva. Provedeno je i kvalitativno istraživanje metodom polustrukturiranih intervjua od lipnja do listopada 2011. godine, koje je obuhvatilo 49 ispitanika. U Hrvatskoj postoje razni modeli informatizacije zdravstva što umanjuje transparentnost i efikasnost cjelokupnoga procesa i u konačnici rezultate prakse e-zdravstva u funkciii unapređenja sustava zdravstva i poboljšanja zdravlja. U radu su identificirani čimbenici o kojima ovisi uspiešnost funkcioniranja e-zdravstva, što omogućuje razvoj sustavne, uspješne i održive strategije razvoja e-zdravstva u Hrvatskoj, koja je nužna.

Ključne riječi: e-zdravstvo, Europska unija, Republika Hrvatska

Rajko Ostojić, Medicinski fakultet Sveučilišła u Zagrebu, Šalata 3, 10000 Zagreb, Hrvatska.

E-mail: rajko.ostojic@gmail.com 
Ključni dio koncepta e-zdravstva jest pouzdano stvaranje, obradba i razmjena informacija u uvjetima brzih promjena i turbulentnog okruženja. Pri tome se naglasak pomiče s tehnologije na ljude, procese i usluge usmjerene k očuvanju i postizanju zdravlja (Rodrigues, 2003.). E-zdravstvo uključuje sljedeće međupovezane kategorije (Callens, 2010.): informacijske sustave za klinički rad i kućnu njegu, personalizirane zdravstvene sustave i usluge za prostorno udaljene pacijente, integrirane regionalne i nacionalne zdravstveno-informacijske mreže, uporabu ostalih sustava potpore (poput sustava naplaćivanja i slično). Nadalje, primjena e-zdravstva ne može se provesti izdvojeno od ostalih usluga zdravstvenoga sustava, pa je potrebna integriranost svih usluga i procesa (Jones i sur., 2007.), ali i interdisciplinarna suradnja timova ljudi zaduženih za planiranje, razvoj, primjenu i njihovo djelovanje.

Tako, primjerice, uporabom e-recepata, jednom od aplikacija e-zdravstva, pacijentima se olakšava dobivanje lijekova, a liječnicima primarne zdravstvene zaštite smanjuje broj posjeta $u$ ordinaciji. Uz to se smanjuju troškovi ispisa na papiru te pojednostavnjuju manipulacije receptima. Samo na smanjenju utroška papira mogu se postići velike uštede (Gell i sur., 2000.). Povezani informatički sustavi davatelja zdravstvenih usluga mogu pridonijeti sprečavanju nepotrebnih medicinskih postupaka, sa značajnom prednosti za pacijente, a uz smanjenje troškova (Juffernburch, 2010.). E-zdravstvo može izravno koristiti pacijentima poboljšavajući kvalitetu njege, poboljšavanjem pristupa medicinskim uslugama i poticanjem samostalnoga življenja starijih i kronično bolesnih osoba (Delegation of the European Union, 2011.). E-zdravstvo može biti korisno s aspekta smanjivanja financijskoga pritiska, povećavajući produktivnost zdravstvenoga sektora i osiguranjem boljih rezultata s manje uloženih resursa (Commission of the European Communities, 2004.).

Kao primjeri najčešćih izazova koji stoje pred praksom i daljnjim razvojem e-zdravstva mogu se izdvojiti (Stroetmann i sur., 2011.):

- nedovoljna informiranost državnih uprava i zdravstvenih vlasti o potencijalnim koristima šire primjene informacijske i komunikacijske tehnologije u zdravstvenom sektoru i ostalim sektorima

- manjak standardizacije

- nedostatak dosljednosti prilikom provođenja donesenih planova i inicijativa

- nedostatak uključenosti medicinskih stručnjaka, kao i onih za IKT, pacijenata i ostalih sudionika zdravstvenoga sustava u razvoj e-zdravstva 
DRUŠ. ISTRAŽ. ZAGREB GOD. 21 (2012),

BR. $4(118)$

STR. 843-862

OSTOJIĆ, R., BILAS, V., FRANC, S.:

E-ZDRAVSTVO.
- nedostatak financijskih sredstava za razvoj e-zdravstva

- $\quad$ komplicirane aplikacije

- nedostatak zakonske regulacije i fragmentacija tržišta e-zdravstva

- bojazan od zlouporabe privatnih podataka

- $\quad$ nejednak pristup uslugama e-zdravstva za sve.

Ustroj i primjena e-zdravstva mogli bi se prikazati ovako (Mađarić, 2009.):

- Informatički servisi primarne i izvanbolničke specijalističko-konzilijarne zdravstvene zaštite: ordinacije obiteljskih liječnika, specijalističke ordinacije, poliklinike i zajedničke prakse (npr. ginekološka, pedijatrijska, stomatološka), laboratoriji, ljekarne (uključivo npr. e-recepti) itd.

- Informatički servisi bolničke zdravstvene zaštite: bolnički informatički sustavi, aplikacije medicinskih specijalnosti (npr. transfuziološka), specijalizirane dijagnostičke aplikacije (radiološki, laboratorijski i drugo), informatička rješenja vezana uz medicinske instrumente (npr. u jedinicama intenzivnoga liječenja, uz ultrazvučnu dijagnostiku i slično), potporne djelatnosti (npr. bolnička prehrana, bolnička ljekarna i drugo).

- Informatički servisi javnoga zdravstva: javno zdravstveno osiguranje, zavodi javnoga zdravstva, specijalizirani registri bolesnika (npr. onkološki, banke tkiva i slično), informatička potpora specijaliziranim procesima (npr. transplantacijskim, higijensko-epidemiološkim, inspekcijskim, akreditacijskim) itd.

- Središnji zdravstveno-informatički servisi (uključivo oni koji su primjenjivi u svim podsustavima): središnje upravljanje sustavom e-zdravstva, usklađeno sa strategijom zdravstvenoga sustava, poslovni informatički podsustavi u zdravstvu, informatička normizacija uključivo certifikacija i sukladnost s (pod)zakonskim propisima, telemedicina, uključivo stvaranje virtualnih zdravstvenih timova te mHealth rješenja (upotreba mobilnih telekomunikacija i multimedijalnih tehnologija $u$ pružanju zdravstvene zaštite), elektronički zdravstveni zapisi, internetski portali za pacijente i zdravstvene profesionalce, informatička sigurnost, informatička edukacija, upravljanje matičnim podacima (npr. katalozi postupaka, dijagnoza...), središnja tehnička osnovica i mrežna infrastruktura, npr. SaaS (eng. Software as a Service) model računarstva u oblaku (softver kao usluge) za ustanove javnoga zdravstva koji omogućuje plaćanje softvera onoliko koliko se stvarno rabi te prilagodbu korisnika sustava u svakom trenutku, kao i opsega funkcija prema potrebama ili jednostavno otkazivanje usluge kada za njom više nema potrebe, središnja nabava i uspostavljanje informatičkih servisa, pogon i transformacija informatičkih servisa, korisnička potpora, komunikacija s drugim informatič- 
DRUŠ. ISTRAŽ. ZAGREB GOD. 21 (2012)

BR. $4(118)$

STR. 843-862

OSTOJIĆ, R., BILAS, V., FRANC, S.:

E-ZDRAVSTVO... kim sustavima (primjerice, registri u državnoj upravi, razmjena informacija za znanstvene potrebe, EU sustavi i inicijative...).

Odluka o financiranju razvoja primjene e-zdravstva mora se temeljiti na cilju modernizacije zdravstvenoga sustava i postavljanju prioriteta te izboru optimalne investicije na temelju procjene potencijalnih koristi i troškova (Dobrev i sur., 2008.). Nadalje, financiranje e-zdravstva mora biti održivo. Paket financiranja mora pokriti čitav životni ciklus projekta te se eventualni problemi financiranja moraju unaprijed predvidjeti i ponuditi prikladna rješenja. Ulaganje u e-zdravstvo podrazumijeva tri zasebna područja ulaganja, od kojih je svako zaseban izazov financiranja (Dobrev i sur., 2008.): (1) razvoj i priprema e-zdravstva, (2) aktivnosti nabave i primjene, (3) upravljanje e-zdravstvom i pokrivanje troškova poslovanja. Mogući izvori financiranja e-zdravstva jesu: ulaganja i subvencije države, regionalni fondovi, privatni ulagači, regionalne, odnosno međunarodne, investicijske banke te međunarodne institucije, kao što su Svjetska zdravstvena organizacija, Svjetska banka i druge.

Što se tiče EU-a, iako svaka zemlja članica samostalno uređuje vlastiti zdravstveni sustav, EU surađuje i pomaže nacionalnim vlastima oko mobilnosti pacijenata, usklađivanja i internoga povezivanja informacijskih i zdravstvenih sustava, infrastrukture, usvajanja inovativnih tehnologija te rješavanja zakonskih pitanja (Delegation of the European Union, 2011.). Poticanje e-zdravstva pridonijelo je stvaranju nove industrije nazvane "industrijom e-zdravstva", koja može postati treća najveća industrija u zdravstvenom sektoru s prihodima većima od 11 milijardi eura (ili oko $5 \%$ ukupnoga proračuna za zdravstvo) (Commission of the European Communities, 2004.). Konačni je cilj stvoriti europsko područje e-zdravstva (engl. European e-Health Area) koje će biti okvir zajedničkoga djelovanja i sinergije u e-zdravstvu i osigurati povoljno okruženje za njegov daljnji razvoj i širenje.

Dostupna istraživanja pokazuju da su, među zemljama članicama EU-a, Danska, Nizozemska, Finska, Švedska i Velika Britanija najuspješnije $u$ e-zdravstvu, dok je u zemljama poput Grčke, Latvije, Litve, Poljske i Rumunjske primjena informacijske i komunikacijske tehnologije (IKT) u zdravstvu na vrlo niskoj razini, što vodi ka zaključku da ni e-zdravstvo nije uvriježena praksa (European Commission, 2007.).

Razvoj e-zdravstva dio je strategije razvoja EU-a nazvane "eEuropa". Europska je komisija 2004. godine donijela tzv. Akcijski plan e-zdravstva kako bi unaprijedila usluge e-zdravstva i razmjenu informacija na internetu i povezanih tehnologija. Tri su ključna područja obuhvaćena planom (Commission of the European Communities, 2004.): 
DRUŠ. ISTRAŽ. ZAGREB GOD. 21 (2012),

BR. 4 (118)

STR. 843-862

OSTOJIĆ, R., BILAS, V., FRANC, S.: E-ZDRAVSTVO.
1. Rješavanje zajedničkih izazova koji uključuju: poticanje tijela zaduženih za zdravstveni sektor na poduzimanje konkretnih i koordiniranih akcija; razvijanje interoperabilnosti zdravstveno-informacijskih sustava; mobilnost pacijenata i profesionalaca; poboljšanje infrastrukture i dostupne tehnologije; usvajanje normi i pravila o kvaliteti zdravstvenih proizvoda i usluga; poticanje ulaganja $\mathrm{u}$ e-zdravstvo te donošenje pravnog okvira.

2. Pokretanje pilot-akcija kako bi se proširila uporaba e-zdravstva.

3. Razmjena iskustava i znanja te mjerenje napretka.

Europska je komisija izradila i plan razvoja digitalnoga tržišta i omogućavanja pristupa pod nazivom Europski digitalni plan (engl. Digital Agenda for Europe). Ovaj je plan dio šire europske strategije razvoja (engl. Europe 2020 Strategy) usmjeren prema definiranju uloge i doprinosa primjene IKT-a u postizanju društvenih i ekonomskih ciljeva navedenih u strategiji. Neki od najvećih izazova i zapreka uključuju (European Commission, 2010.): rascjepkanost digitalnoga tržišta, nedovoljnu suradnju i standardizaciju, povećan rizik od mrežnoga (engl. cyber) kriminala i nedostatak povjerenja u mreže, nedovoljna ulaganja u izgradnju mreža, nedovoljno istraživanja i razvoja, izostanak digitalne pismenosti te nedovoljno iskorištavanje IKT-a za rješavanje društvenih izazova.

Efikasna praksa e-zdravstva jedan je od osnovnih ciljeva $\mathrm{u}$ okviru šire nacionalne strategije razvitka hrvatskoga zdravstva (Jurković, 2011.) te se posebno ističe uvođenje elektroničkog recepta (e-recept), elektroničke uputnice (e-uputnica), elektroničkoga naručivanja (e-naručivanje) i elektroničkoga zdravstvenog zapisa (e-zapis) i slično. Prepoznato je značenje IKT-a, što se vidi i po informatizaciji sustava primarne zdravstvene zaštite. Cilj je unaprijediti zdravstveni sustav tako da zadovolji potrebe građana Republike Hrvatske za kvalitetnom zdravstvenom skrbi, koja obuhvaća sprečavanje bolesti, edukaciju o zdravlju, rano prepoznavanje rizika bolesti te liječenje i rehabilitaciju bolesnih. U skladu s navedenim, ulažu se i sve veći napori na području razvoja telemedicine, pa je 2005. godine osnovan Hrvatski zavod za telemedicinu Uredbom Vlade Republike Hrvatske. Mađarić (2009.) navodi sljedeće glavne ciljeve e-zdravstva: poboljšanje kvalitete zdravstvene skrbi za pacijente, olakšanje rada zdravstvenog osoblja, bolje upravljanje zdravstvenim sustavom i smanjenje troškova (bez štete za pacijente i zdravstveno osoblje). E-zdravstvo može imati presudnu potpornu ulogu u prevenciji. Jedan od primjera jest dizajn "Socijalne mreže za sprečavanje dječjih ozljeda" u Hrvatskoj (Mađarić i sur., 2011.a). 
Rad prikazuje dio istraživanja, odnosno analizira se jedan od ukupno devet istraživačkih problema obuhvaćenih širim istraživanjem, i to: informatizacija i e-zdravstvo. Primarna svrha provedenoga istraživanja bila je razviti razumijevanje stanja i perspektiva budućega razvoja zdravstvenoga sustava Republike Hrvatske s nacionalnog aspekta, ali i regionalnoga, odnosno s aspekta EU-a. Analiziralo se stanje danas (2011. godine) te perspektive razvoja i možebitno stanje u budućnosti (2030. godine), a potaknuto je recentno objavljenim rezultatima Economic Intelligence Unit-a o budućnosti zdravstvenoga sustava EU-a i predviđanjima za 2030. godinu (Economist Intelligence Unit, 2011.). Analiza i stanja i perspektiva budućega razvoja omogućuje kvalitetnije rezultate i s aspekta preporuka smjernica za provođenje politika kojima bi se minimizirali potencijalni negativni razvoji i ubrzali mogući pozitivni razvoji. U sklopu provedenoga šireg istraživanja unaprijed je definirano ukupno devet istraživačkih problema: ključni problemi, politika lijekova i ugradbenih materijala, prava pacijenata, kvaliteta, financiranje, odnos javnoga i privatnoga zdravstva, informatizacija i e-zdravstvo, ljudski resursi i plaće te nacionalni zdravstveni sustavi u EU-u i implikacije ulaska Republike Hrvatske u EU. Fokusiranjem na navedenih devet segmenata istraživanja pokrivene su sve ključne točke potrebne za analizu stanja i perspektiva zdravstvenih sustava Republike Hrvatske i zemalja članica EU-a. Cilj segmenta istraživanja prikazanog $u$ ovom radu jest razumijevanje razine $\mathrm{i}$ perspektiva upotrebe i razvoja informatizacije i prakse e-zdravstva u Republici Hrvatskoj, kao i identificirati osnovne probleme i eventualne zapreke $u$ daljnjem razvoju informatizacije i prakse e-zdravstva u zdravstvenom sustavu Republike Hrvatske.

\section{METODE ISTRAŽIVANJA}

Kao osnovna metoda istraživanja odabran je polustrukturirani intervju, koji se može provesti audiosnimanjem razgovora, internetom (chat, e-mail...) i/ili telefonskim razgovorom (Saunders i sur., 2007.). U polustrukturiranom intervjuu istraživač ima popis pitanja ili specifičnih tema, koje se često nazivaju i vodičem za intervjue, ali ispitanici imaju slobodu u odgovaranju. Pitanja ne moraju nužno slijediti redoslijed, pa se mogu postavljati i pitanja koja nisu uključena u sam vodič. Neizbježan i vrlo važan aspekt ove vrste istraživanja jest doprinos istraživača koji interpretira riječi ispitanika (Stenius i sur., 2008.). Posebna vrijednost kvalitativnog istraživanja jest sposobnost da se dubinski istraže elementi i formiraju perspektive čiji su koncepti, smisao i objašnjenja induktivno razvijena iz empirijskih podataka (Hruška, 2010.). Primarna pred- 
DRUŠ. ISTRAŽ. ZAGREB GOD. 21 (2012), BR. 4 (118),

STR. 843-862

OSTOJIĆ, R., BILAS, V., FRANC, S.: E-ZDRAVSTVO.. nost metode dubinskih intervjua jest $u$ pružanju detaljnijih informacija nego što je to moguće drugim metodama prikupljanja podataka (Boyce i Neale, 2006.).

Istraživanje je provedeno od lipnja do listopada 2011. godine u sklopu šireg istraživanja, kojem je primarna svrha razviti razumijevanje stanja i perspektiva budućega razvoja zdravstvenoga sustava Republike Hrvatske, a kako je već navedeno. Cilj uzorkovanja u kvalitativnim istraživanjima fundamentalno je drugačiji od uzoraka upotrijebljenih u kvantitativnim istraživanjima. Kvalitativno istraživanje treba objasniti obrasce ponavljanja odabranih elemenata istraživanja, a ne tek jednostavno utvrditi da oni postoje (White i sur., 2003.). Način definiranja uzorka u kvalitativnim istraživanjima obično je smislen ili teoretski, za razliku od slučajnog uzorkovanja ili nekoga drugog pristupa kojim se želi osigurati statistička reprezentativnost (Maxwell, 2002.). U teorijski uzorak odabiru se slučajevi koji mogu replicirati ili proširiti pretpostavljenu teoriju (Eisenhardt, 1989.). Glavno istraživanje provelo se nad ispitanicima koji su relevantni za analizu postavljenih problema, a predstavljaju zdravstvene profesionalce (liječnici, stomatolozi, farmaceuti, biokemičari, medicinske sestre, primalje i drugi) iz javnoga i privatnoga sektora, zdravstvene osiguravajuće tvrtke, farmaceutske tvrtke i veledrogerije te nevladine udruge, odnosno udruge pacijenata. $U$ glavnom istraživanju provedeni su intervjui sa 49 ispitanika, od kojih je 23 zdravstvenih profesionalaca, 8 predstavnika zdravstvenih osiguravajućih institucija, 10 predstavnika farmaceutskih kompanija i dobavljača, 8 predstavnika udruga pacijenata, među kojima je i koalicija udruga koja pokriva 70 udruga pacijenata. Vodilo se računa o izboru ispitanika s aspekta pristranosti, odnosno da se osigura nepristranost te da se radi o onim ispitanicima koji su relevantni za predmetno područje te imaju dosta informacija i mogu pridonijeti utvrđivanju značajki, nedostataka i prednosti prakse e-zdravstva u sustavu zdravstva Republike Hrvatske. Svi ispitanici pristali su na provedbu intervjua. Nakon provedbe intervjua poslana su pisma zahvale.

Etička su pitanja zastupljena u svim tipovima istraživanja (Orb i sur., 2001.). Ispitanici se moraju informirati o ciljevima istraživanja i glavnim crtama istraživanja (Kvale, 1996.). Istraživačka etika primarno se bavi interakcijom istraživača i ispitanika (Mack i sur., 2005.). Temeljna etička pitanja o kojima se vodilo računa prilikom ovog istraživanja jesu: pristanak ispitanika, privatnost i tajnost podataka. Što se tiče zadiranja u privatnost, u kontekstu ovog istraživanja, smatra se da pitanja nisu ulazila u područje privatnoga života ispitanika, pa, prema tome, nema nikakvih etičkih implikacija u provedbi istraživanja. Ispitanicima je obećana tajnost podataka i anonimnost, pa se o ovim etičkim dimenzijama i vodilo računa. Ime- 
DRUŠ. ISTRAŽ. ZAGREB GOD. 21 (2012)

BR. $4(118)$

STR. $843-862$

OSTOJIĆ, R., BILAS, V., FRANC, S.:

E-ZDRAVSTVO... na ispitanika ne pojavljuju se $\mathrm{u}$ tekstu, dodijeljene su oznake "I" i redni brojevi od 1 do 49 (I1,...I49) prema slučajnom redoslijedu obradbe pojedinog intervjua. Nadalje, $u$ analizi se ne spominju ni imena ili slični podaci koje su spominjali sami ispitanici prilikom intervjua, s obzirom na to da ne znače ništa u konačnim rezultatima istraživanja. Istraživanje je provedeno u tri osnovne faze:

1. Pozadinsko istraživanje: upoznavanje s problemskim područjem istraživanjem literature.

2. Konstruiranje glavnog istraživanja.

3. Glavno istraživanje (vidjeti Kvale, 1996.), koje je obuhvatilo 49 ispitanika.

3.1. Prvi korak: sintetiziranje glavnih tema.

3.2. Drugi korak: analiza.

3.3. Treći korak: interpretacija rezultata.

3.4. Četvrti korak: verifikacija i izvještavanje.

Faza pozadinskog istraživanja, odnosno istraživanje relevantne literature, bilo je prva faza istraživanja stanja i perspektiva zdravstvenoga sustava Republike Hrvatske. U ovoj fazi istraživanja postupno su se konstruirale teme i područja iz kojih su se formirala pitanja za treću fazu istraživanja. Uz upoznavanje s literaturom, $u$ ovoj su fazi obavljeni i brojni neformalni razgovori o stanju i perspektivama razvoja zdravstvenih sustava Hrvatske i zemalja EU-a s mnogim istaknutim djelatnicima iz sektora javnoga zdravstva, farmaceutske industrije, s liječnicima i drugima. U ovoj istraživačkoj fazi ideja je bila dubinski analizirati problematiku. Druga faza bila je konstruiranje glavnog istraživanja. Istraživanje se temelji na sljedećim metodološkim ciljevima (vidjeti Hruška, 2010.): istražiti dubinski relevantnu literaturu i druge sekundarne izvore podataka o stanju i perspektivama razvoja zdravstvenih sustava Republike Hrvatske i zemalja članica EU-a; prikupiti dovoljno empirijske građe za dubinsko razumijevanje društvenoga, kulturnoga i ekonomskoga konteksta unutar kojih funkcioniraju analizirani zdravstveni sustavi; utvrditi postavljeni konceptualni okvir u empirijskim podacima; obrazložiti i definirati istraživački pristup; provesti dubinske intervjue s predstavnicima zdravstvenih profesionalaca iz javnoga i privatnoga sektora, predstavnicima zdravstvenih osiguravajućih tvrt$\mathrm{ki}$, predstavnicima farmaceutskih tvrtki i veledrogerija te predstavnicima nevladinih udruga, odnosno udruga pacijenata; analizirati prikladnim analitičkim metodama provedene intervjue; prikazati sve korake prikupljanja podataka i procesa analize, kako bi se upozorilo na validnost i transparentnost procesa istraživanja i dobivenih rezultata te prikaz teoretskih i 
DRUŠ. ISTRAŽ. ZAGREB GOD. 21 (2012),

BR. 4 (118),

STR. 843-862

OSTOJIĆ, R., BILAS, V., FRANC, S.:

E-ZDRAVSTVO praktičnih implikacija i preporuka proizašlih iz provedenoga istraživanja.

U definiranju rezultata istraživanja stanja primijenjene su dvije perspektive zaključivanja: ispitanika i istraživača, koja je izvedena iz interpretacije prikupljenih podataka.

Pristup analizi podataka vrlo je sličan onom što ga predlaže Rabiee (2004.). U istraživanju je primijenjen analitički pristup za reduciranje i sintetiziranje tekstualnih podataka. Da bi se postigla transparentnost, jasnoća i mogućnost koherentnoga restrukturiranja analitičke strukture, uzeta je struktura analitičke hijerarhije koja se zasniva na: (1) obradbi podataka, (2) opisu podataka i (3) objašnjenju definiranih kategorija (Spencer i sur., 2003.).

Obradba podataka čini prvi dio analize i obuhvaća generiranje skupa tema i koncepata prema kojima se dijelovi empirijskih podataka označuju, sortiraju i sintetiziraju. U ovom se dijelu analize temeljito upoznaje s empirijskom građom, što je vrlo važno za kasnije interpretativne faze analize. Nakon razvoja tipologija i opisa slijedi faza objašnjavanja definiranih kategorija. Nakon provedenoga postupka kodiranja, upotrijebljena je metodologija induktivne analize, koja uključuje detaljan pregled prikupljene građe u traganju za riječima, frazama i rečenicama koje mogu indicirati određene probleme. Povezujući razne segmente analize koji sami za sebe imaju visoku konceptualnu i empirijsku važnost, možemo doći do konceptualnih shema koje pokazuju veću razinu konceptualne integracije i dosega (Dey, 1993.). Naravno, teme koje se identificiraju i kategoriziraju uključuju i provizorni istraživački okvir i interpretacije istraživača. Analiza podataka nije samo mehanička potvrda reflektiranja iz podataka, pa je u ovom istraživanju naglasak stavljen na važnost, a ne na brojnost iskaza (Dey, 1993.; Hruška, 2010.).

Nadalje, induktivna analiza pruža priliku da se jave teme koje ne proizlaze izravno iz inicijalnoga istraživačkog okvira. Temeljni korak u reorganiziranju podataka jest kodiranje podataka, koje se obično temelji na odvajanju dijelova teksta i njihovu pridruživanju pojedinim temama. Kodiranje nije samo označavanje teksta, jer se kroz proces označavanja povezuje značenje podataka i sami podaci, što omogućuje usporedbu između dijelova podataka, a temelj je konceptualne interpretacije podataka (Dey, 1993.). Neki kod može nastati iz intervjua s ispitanicima ili ga može konstruirati sam istraživač. No ispravna veličina koda, u smislu je li to riječ, rečenica ili ulomak transkripta, kao i mjera do koje je pitanje veličine konzistentno upotrijebljeno stvar je odabira istraživača. Podaci moraju sadržavati značenje za konkretni istraživački problem. Mogu sadržavati i razmišljanja istraživača, interpretacije i pitanja (Miles i sur., 1994.). 
DRUŠ. ISTRAŽ. ZAGREB GOD. 21 (2012)

BR. $4(118)$

STR. $843-862$

OSTOJIĆ, R., BILAS, V., FRANC, S.:

E-ZDRAVSTVO.
Kako bi se izbjegao neželjeni utjecaj vremenskoga redoslijeda analize intervjua, jer ranije analizirani utječu u većoj mjeri od onih analiziranih kasnije, pojedinačni iskazi sistematizirani su u 9 segmenata koji korespondiraju s istraživačkim pitanjima.

Završna faza analize uključuje induktivnu analizu podataka, svrha koje je generalizacija prema novim teorijskim obrascima, odnosno prema konstruiranju smjernica za izradbu kvalitetne i održive strategije razvoja zdravstvenoga sustava Republike Hrvatske.

Vodilo se računa o triangulaciji kao metodi provjere i uspostavljanja validnosti provedenog istraživanja (Guion, 2002.), i to o triangulaciji podataka, istraživača, teorijskoj te metodološkoj triangulaciji. Triangulaciju kao metodu provjere pouzdanosti i validnosti kvalitativnih istraživanja preporučuje i Golafshani (2003.).

\section{REZULTATI ISTRAŽIVANJA}

Osnovne teme istraživanja zovu se metakodovima. U sklopu provedenog istraživanja bilo ih je devet, i to unaprijed određenih, kako je već navedeno. Metakod elaboriran u ovom radu označen je u procesu provedbe istraživanja oznakom H7. Prema višerazinskom principu, na isti su način prikazani i pripadajući kodovi: procjena stanja i preporuke razvoja. Kodiranje se temelji na odvajanju dijelova teksta te njihovu pridruživanju pojedinim temama. Što se tiče distribucije kodova kroz teme, 148 ih se odnosi na metakod "informatizacija i e-zdravstvo u RH", a od čega ih se na procjenu stanja 2011. godine, odnosi 77 ili 52\%, na procjenu stanja 2030. godine 28 ili 19\%, na preporuke razvoja 2011. godine 29 ili $20 \%$, a u budućnosti, odnosno 2030. godine, 14, odnosno 9\%.

Što se tiče razine informatizacije i prakse e-zdravstva $u$ Republici Hrvatskoj te njezinih prednosti i nedostataka, mišljenja ispitanika variraju. Tako I11 smatra da je informatizacija fragmentirana i ocjenjuje primjenu normi nedovoljnom, dok ima mišljenja kako je još u povojima (I37, I39) ili nerazvijena (I40). Svakako se informatizacija smatra nužnom (I2, I5), ali dosadašnje rezultate neki ocjenjuju skromnima (I2, I29) i dobrim početkom (I3, I41); I42 smatra kako e-zdravstvo postaje "iznenađujuće dobro, naročito u primarnoj zdravstvenoj zaštiti". Informatizacija u ljekarničkim ustanovama smatra se uspješnom i potpuno provedenom (I46), uz probleme poput neažuriranih podataka o osiguranim osobama kod liječnika ili samoga Hrvatskog zavoda za zdravstveno osiguranje (HZZO) (I46).

Od prednosti ističu se uštede (I31), zamjetni pozitivni rezultati od uvođenja e-recepata i e-uputnica, koje pomažu pacijentima (I3, I8, I34), napredak u kontroli potrošnje (I14), preglednosti lista čekanja (I14, I1). Nadalje, informatizacija pri- 
DRUŠ. ISTRAŽ. ZAGREB GOD. 21 (2012), BR. $4(118)$

STR. 843-862

OSTOJIĆ, R., BILAS, V., FRANC, S.: E-ZDRAVSTVO. marne zdravstvene zaštite opisuje se kao snaga hrvatskoga zdravstvenog sustava (I6), uvođenje većega reda u poslovanje (I9), poboljšanje transparentnosti sustava (I9). Od ukupnoga broja ispitanika, $16,3 \%$ ih ističe prednosti informatizacije hrvatskoga zdravstvenog sustava.

Na probleme informatizacije i uvođenja e-zdravstva osvrće se $24,4 \%$ ispitanika te posebno ističu problem tajnosti podataka o pacijentima (I15, I28, I32), ali i problem netransparentnosti (I11, I28). Nadalje, istaknut je i problem prisutnosti raznih modela informatizacije (I8, I18), izostanka planske analize (I17) te problem "informatizacije primarne zdravstvene zaštite u hodu" (I17), kao i nametanja rješenja HZZO od vlastita interesa (I8). Kao problem navodi se i slaba educiranost zdravstvenog osoblja (I9, I18, I30, I28), nedovoljna količina informatičke opreme (I30), često nefunkcioniranje sustava (I9, I30, I34) te upitnost točnosti informacija o lijekovima koje se nalaze u samom sustavu (I9), ali i nedovoljna primjena telemedicine na otocima i drugim teže pristupačnim područjima (I25).

Što se tiče telemedicine, I28 smatra da je na nju potrošeno previše sredstava, a nikada nije proradila. Navodi se i činjenica (I18) beskorisnosti osobnoga identifikacijskog broja (OIB): "preko OIB-a se ne može vidjeti do kada pacijentu vrijedi osiguranje", nejedinstvenosti e-tiskanica za cijelo područje Hrvatske (I28); I36 smatra da je puno gubitaka u procesu informatizacije i uvođenja e-zdravstva proizišlo iz pogrešnoga planiranja, I47 smatra kako još nisu omogućene očekivane uštede od informatizacije zdravstvenoga sustava, dok I49 upozorava na podložnost velikim kvarovima centraliziranoga i informatiziranoga zdravstvenog sustava. Spominje se i korupcija u razvoju informatizacije i prakse e-zdravstva (I27); I31 smatra kako se kontakti liječnika i pacijenata nisu popravili, iako "liječnici imaju više vremena". Uočava se kako postoji i nepovezanost primarne i bolničke zdravstvene zaštite (I4: "pacijenti ne trebaju nositi nalaze po gradu"), odnosno svih razina zdravstvene zaštite (I28); I7 smatra kako su pokušaji informatizacije više pridonijeli olakšavanju administrativnoga posla, a ne kvaliteti pružanju same usluge (I7: "u uređenom sustavu informatizacija bi trebala omogućiti liječniku primarne zdravstvene zaštite ugovaranje specijalističkog pregleda ili pretrage bez osobnog odlaska pacijenta ili člana njegove obitelji"). Trenutačnu informatizaciju hrvatskoga zdravstvenog sustava I28 ocjenjuje više kao kontrolni mehanizam administracije nego ostvarivanja korisnosti u smislu stručnih, medicinskih programa; I22 unatoč pozitivnoj ocjeni o primjeni bolničkoga informatičkog sustava u mnogim bolnicama u RH ističe kako "bolnice pojedinačno nemaju šanse implementirati kvalitetne i održive bolničke sustave" zbog ekonomije obujma, nedostatka stručnjaka, nedostatka sredstava iz redovitoga poslovanja itd. 
DRUŠ. ISTRAŽ. ZAGREB GOD. 21 (2012)

BR. 4 (118)

STR. $843-862$

OSTOJIĆ, R., BILAS, V., FRANC, S.:

E-ZDRAVSTVO..
I45 smatra kako aktualni proces informatizacije hrvatskoga zdravstva nije vođen po pravilima struke, jer se "informatizirati treba samo organizirani sustav", pa će se nastojati tek u drugoj fazi ostvariti primarni cilj "kvalitetnije zdravstvene usluge pacijentima i kvalitetnije radno okruženje zdravstvenim profesionalcima". Na daljnje prijedloge razvoja osvrće se gotovo $40 \%$ ispitanika te tako I13 predlaže "omogućiti kvalitetnu edukaciju medicinskom osoblju u korištenju informatičkih tehnologija", odnosno nastavak edukacije zdravstvenog osoblja (I33), ali i pacijenata (I32); I35 upozorava kako je potrebno učiniti sve da se održi odnos pacijenta i liječnika, odnosno da se taj odnos ne svodi isključivo na gledanje u računalo. Isto navode i Mađarić i Nesek-Mađarić (2011.b) u prezentaciji o ulozi IT-a u bolnici "prijatelju pacijenata", opisujući glavne blokatore kojima IKT odvlači pozornost liječnika od pacijenta.

I21 smatra kako treba uvesti pravila sigurnosti i nadzor, osnovati otvorene radne skupine za e-zdravstvo, da HZZO treba organizirati javne tribine, povećati transparentnost, omogućiti daljnji razvoj e-kartona i e-potpisivanja liječnika te opskrbiti liječnike i ustanove potrebnom opremom za upotrebu informatičke tehnologije. Za bolju kontrolu sustava zalaže se i I49. Posebno treba pacijentima osigurati tajnost podataka (I32); I29 smatra kako je "neophodno ujednačiti informatičke sustave, učiniti dostupnima odgovarajuće podatke na svim razinama zdravstvene zaštite $\mathrm{u}$ interesu korisnika i davatelja $\mathrm{u}$ sluga", odnosno racionalizirati i učiniti efikasnom dostavu podataka HZZO-u, jer smatra kako se dostavljaju podaci koje nitko ne rabi, a njihovo prikupljanje i dostava povećavaju ustanovama troškove. I25 predlaže da se dodatno osigura izdavanje lijekova e-receptima od mogućih zlouporaba, I35 ističe konkretan prijedlog što se tiče samih programa, a to je vezati šifru uz opis postupka; I45 i I22 predlažu zasebnu agenciju za upravljanje zdravstvenim informacijskim sustavom, a ne da to bude HZZO. To je i najvažnija preporuka "Deklaracije o e-zdravlju", koju je 2011. godine donijela Akademija medicinskih znanosti Hrvatske.

Što se tiče razine informatizacije i prakse e-zdravstva u Republici Hrvatskoj do 2030. godine, 43\% ispitanika predviđa daljnji razvoj (I1, I2, I13, I14, I17, I33, I34, I16, I39, I40, I41) i usklađenost s praksom zemalja članica EU-a (I11, I4, I28). To znači da će se poštovati kriteriji za utvrđivanje kvalitete i evaluacije e-proizvoda te da će postojati za to nezavisno tijelo (I11), odnosno da će Hrvatska biti uključena u paneuropski interoperabilni sustav (I5). Postići će se informacijska povezanost i umreženost svih razina u sustavu zdravstva (I28, I37). Smatra se kako s obzirom na sve prednosti treba ustrajati na sustavnom unapređenju postojećih i uvođenju novih rješenja (I15, I3), a I2 kako će današnji problemi "biti stvar povijesti". 
DRUŠ. ISTRAŽ. ZAGREB GOD. 21 (2012), BR. 4 (118),

STR. $843-862$

OSTOJIĆ, R., BILAS, V., FRANC, S.: E-ZDRAVSTVO

\section{RASPRAVA}

$\rightarrow$ SLIKA 1 E-zdravstvo u Republici Hrvatskoj

I9 smatra da će se do 2030. godine poboljšati infrastruktura, uvesti zdravstveni portali korisni i za pacijente i liječnike te razviti telemedicina. Također, smatra kako će liječnici i pacijenti komunicirati i e-mailom, a za što će liječnici biti dodatno nagrađivani. I28 smatra da će do tada biti uspostavljen osjetan napredak i u mjerama sigurnosti i zaštite podataka, a I47 očekuje i znatne uštede; I32 smatra kako će i 2030. godine biti potrebno provoditi kontrolu, I22 smatra da zbog nepredvidivosti napretka IKT-a treba planirati e-zdravstvo u 5-godišnjem rasponu te razrađuje niz područja koja bi trebalo uvesti do 2015. godine. Kao temeljni uvjet za sustizanje razine e-zdravstva u EU-u navodi žurno osnivanje krovne organizacije za e-zdravstvo, koja bi uspostavljala nacionalne i institucionalne sustave te osigurala standardizaciju i regulativu. Takva institucija trebala bi biti stručna i nezavisna, njezine aktivnosti odgovarajuće financirane, a izvršenje utvrđenih planova nadzirano od Saborskog odbora za zdravstvo.

Do 2030. godine bit će važno "omogućiti kontrole bolesnika korištenjem informatičke metodologije bez dolaska bolesnika u zdravstvenu ustanovu" (I36) zbog velikoga broja osoba s kroničnim bolestima. I36 smatra najvažnijim razvoj informatizacije "sustavno, bez iznenadnih promjena i privatnih interesa". Iznenadne promjene odnose se u prvom redu na političke promjene.

Slika 1 prikazuje osnovne rezultate ovoga dijela provedenog istraživanja o informatizaciji i praksi e-zdravstva. Cilj je stvoriti jedinstven informacijski i komunikacijski sustav za sigurnu, efikasnu i transparentnu razmjenu medicinskih podataka (Pejakić, 2009.). Osobit je naglasak na obrazovanju zaposlenika u zdravstvu i uopće na uspostavi sustava. To je golem organizacijski pothvat za koji treba imati jasnu viziju i strategiju, čvrstu odlučnost i podršku na najvišoj razini te kompetentno vodstvo (Pale, 1998.).

2011.

- različiti modeli informatizacije

- problem netransparentnosti

- nerazvijena infrastruktura

- problem zaštite podataka

- slaba educiranost zdravstvenog osoblja

- nefunkcioniranje informatičkih sustava
2030.

- daljnji razvoj informatizacije i e-zdravstva

- informacijska povezanost i umreženost svih razina u sustavu

- uvođenje novih rješenja 
DRUŠ. ISTRAŽ. ZAGREB GOD. 21 (2012) BR. 4 (118)

STR. 843-862

OSTOJIĆ, R., BILAS, V., FRANC, S.:

E-ZDRAVSTVO...
Neka e-rješenja u zdravstvu Republike Hrvatske, uvedena proteklih godina, poput središnjega naručivanja i e-recepata, dovela su do osjetnog unapređenja i povećanja efikasnosti zdravstvenoga sustava, no kako je već navedeno, ima još prostora za dodatna poboljšanja i pojednostavnjenja.

Usluga naručivanja nije dostupna građanima, nego se uputnica mora faksirati ili poslati mailom jedinici za centralno naručivanje određenoga bolničkog centra. Datum i vrijeme pregleda dobivaju se mailom ili čak klasičnom poštom, što ispada "poluautomatski" i nije u skladu s modernim IKT-om i mogućnostima. Trebalo bi omogućiti građanima (ili obiteljskim liječnicima) izravno naručivanje $\mathrm{u}$ taj sustav web-sučeljem.

Uočeno je da pojedine bolnice i bolnički odjeli zasebno vode evidenciju pacijenata i njihove kartone. Kad god pacijent prvi put dođe na takav odjel, otvara se njegov "karton" u lokalnom računalu, što nije vidljivo i dostupno iz cijeloga zdravstvenog sustava. U današnje vrijeme komunikacijskih tehnologija takve sustave treba međusobno povezati i podatke smještati u centralnu zajedničku bazu podataka o pacijentima, vodeći računa o privatnosti i tajnosti podataka. Svaka bolnica i dom zdravlja ima svoje specifično rješenje za administrativne potrebe, što otežava održavanje i razmjenu podataka i dalje svodi na tiskanje na papir i fizičko slanje dokumenata. To je velik prostor za ujednačavanje i povezivanje sustava, što bi omogućilo veće uštede i efikasnost sustava. Iako se proteklih godina prisutnost i kvaliteta širokopojasnog interneta u Republici Hrvatskoj zamjetno proširila, još to nije razina kakva se očekuje od sustava kakav je zdravstveni. Zbog toga se često događa da pacijent ne može do kraja i na vrijeme ostvariti zdravstvenu uslugu. U tom smislu trebalo bi osigurati veću kvalitetu komunikacija, ali i unaprijediti programska rješenja, i to tako da, koliko je to objektivno moguće, rade neovisno o kraćim komunikacijskim problemima. Neka web-rješenja previše ograničavaju i vezana su za jednu vrstu i verziju internetskoga preglednika. Takva rješenja treba hitno uskladiti sa smjernicama o otvorenim standardima, interoperabilnosti i multiplatformnosti. Poseban problem $\mathrm{u} \mathrm{Hr}-$ vatskoj jesu web-stranice koje nisu u skladu s odgovarajućim standardima (WCAG - engl. Web Content Accessibility Guidelines) (WCAG, 2. 3. 2012.), a zbog toga nisu dostupne upravo onima koji ih najviše trebaju - osobama s posebnim potrebama, što valja uskladiti prilikom unapređenja postojećih i izradbe novih web-stranica. Brojni su prijedlozi IKT stručnjaka za unapređenje e-zdravstva u Hrvatskoj, a većinom se svode na aplikaciju efikasnih praksi iz drugih zemalja. Primjerice, zdravstvena e-kartica bazirana na otvorenom kodu iz Austrije 
DRUŠ. ISTRAŽ. ZAGREB GOD. 21 (2012), BR. 4 (118),

STR. 843-862

OSTOJIĆ, R., BILAS, V., FRANC, S.: E-ZDRAVSTVO ili rješenja otvorenoga koda za zdravstvo u vidu SESLinEX.a u Španjolskoj i slično.

Potreba poboljšanja zdravstvenoga sustava i razvoja novih proizvoda i usluga te stvaranja novih načina i kanala pružanja usluga nije upitna. Promjene koje se događaju u globalnom okruženju utječu na stil života i zdravlje ljudi, a usporedno s razvojem ostalih sektora i zdravstveni se sektor stalno mora prilagođavati promjenama i novim uvjetima kako bi se zadovoljila potražnja i održala konkurentnost. Uporaba tehnologije i novih načina komunikacije $u$ osobne i poslovne svrhe postala je uvriježena širom svijeta. Uzima se da su e-zdravstvo, kao i ostali načini e-poslovanja (e-trgovina, e-vlada i drugo) budućnost, no još postoje poteškoće na putu njihove šire primjene.

Kako bi se nastavio razvoj i širenje e-zdravstva, treba koordinirano djelovati: povezati privatne, javne i društvene napore s ciljem brzoga i efikasnoga širenja novih tehnoloških rješenja i omogućavanja pristupa informacijskim i komunikacijskim tehnologijama globalno. Prvi korak prema stvaranju uvjeta za prihvaćanje i praksu e-zdravstva jest provođenje reformi telekomunikacijskoga sustava i prevladavanje digitalnoga jaza. Unapređenje telekomunikacijskoga sustava preduvjet je za informatizaciju zdravstva i povećanje konkurentnosti na globalnom tržištu.

Upravljanje sustavom e-zdravstva još je jedan problem. Suradnja vlade i svih sudionika zdravstvenoga sustava potrebna je kako bi praksa e-zdravstva bila uspješna i efikasna. Valja uložiti zajedničke napore $\mathrm{u}$ izgradnju potrebne infrastrukture i stvaranje prikladnih strategija razvoja i primjene, kao i osigurati nadzor nad djelovanjem. Nadalje, važna je uloga vlade u pogledu poticanja obrazovanja i usavršavanja na području informacijskih sustava i tehnologije, financiranja istraživanja i razvoja, osiguravanja efikasne alokacije resursa, donošenja prikladnog pravnog okvira, koji bi, između osta$\log$, osigurao zaštitu sigurnosti i privatnosti podataka (Ostojić i sur., 2012.).

Potreba za daljnjom standardizacijom izazov je koji valja što prije riješiti. Osim standardizacije, integracija e-zdravstva u cjelokupan zdravstveni sektor vrlo je važna. Na taj se način mogu jednostavnije pronaći izvori financiranja potrebni za daljnja istraživanja i razvoj. Ulaganja u e-zdravstvo valja promatrati i kao komplement, ali i kao supstitut ulaganjima u ostatak zdravstvenoga sustava.

Kvalitetan, dobro organiziran i efikasan zdravstveni sustav koji potiče inovacije kao što je e-zdravstvo donosi koristi pojedincu, ali i čitavom društvu i ekonomiji. Iako računala i tehnologija ne mogu zamijeniti čovjeka, itekako mogu o- 
DRUŠ. ISTRAŽ. ZAGREB GOD. 21 (2012)

BR. $4(118)$

STR. 843-862

OSTOJIĆ, R., BILAS, V., FRANC, S.:

E-ZDRAVSTVO.. lakšati poslovanje, mobilnost, razmjenu i komunikaciju. Što je više informacija dostupno, to je manja mogućnost nastanka pogreške. Sve navedeno upućuje na velik potencijal e-zdravstva u budućnosti, štoviše, ono će postati imperativ modernoga društva.

Upravljanje inovacijom treba vidno promovirati u svim društvenim djelatnostima (Mađarić, 2009.-2010.), a osobito u zdravstvu. Ono se ne smije svesti samo na inovativne lijekove, nove medicinske uređaje i e-zdravstvo, nego poglavito na kontinuirano unapređenje procesa. Kriteriji pod kojima se korisne ideje pretvaraju u upotrebljivu inovaciju u zdravstvu jasni su: boljitak za pacijenta, olakšanje rada osoblju i smanjenje troškova, uz zadržavanje ili povećanje kvalitete zdravstvene zaštite.

\section{ZAKLJUČAK}

Na temelju provedenog istraživanja opisanog $\mathrm{u}$ ovome radu nastojalo se dobiti uvid i postići bolje razumijevanje razine i perspektiva primjene te razvoja informatizacije i prakse e-zdravstva u Hrvatskoj, kao i identificirati temeljne probleme i zapreke daljnjem razvoju informatizacije i prakse e-zdravstva u zdravstvenom sustavu Hrvatske. Rezultati dijela istraživanja o procjeni stanja pokazuju da je informatizacija hrvatskoga zdravstvenog sustava tek na počecima. Ima više modela informatizacije, što umanjuje transparentnost cjelokupnoga procesa. Još nema dovoljno razvijene infrastrukture, koja je preduvjet uspješne prakse e-zdravstva. Ograničavajući su čimbenici i slaba educiranost zdravstvenog osoblja za rad u e-zdravstvu te problem očuvanja tajnosti podataka. Unatoč određenim problemima, informatizacija sustava je nužna i očekuje se njezin daljnji razvoj i napredak.

Rezultati dijela istraživanja o preporukama razvoja upućuju na čimbenike o kojima ovisi uspješnost funkcioniranja e-zdravstva, pa su kao takvi važni, jer njihovo identificiranje omogućuje razvoj sustavne, uspješne i održive strategije razvoja e-zdravstva u Republici Hrvatskoj u funkciji unapređenja i sustava zdravstva i zdravlja građana. To su u prvom redu standardizacija sustava e-zdravstva, odnosno IKT rješenja, razvijena i dostupna infrastruktura, efikasno upravljanje sustavom e-zdravstva, educiranost zdravstvenog osoblja za rad u e-zdravstvu, osiguranje tajnosti podataka, koordinirano djelovanje svih aktera, dostupna financijska sredstva, stavljanje pacijenata i njihovih potreba u središte razvoja strategije u smislu razvoja prioriteta i mjera, omogućavanje jednake dostupnosti i kvalitete zdravstvene zaštite. Predviđa se usklađenost s europskim standardima te postizanje informacijske povezanosti i umreženosti svih razina u sustavu zdravstva. Uvođenje sustava kontrole također je istaknuto kao nužan preduvjet uspješne prakse e-zdravstva u budućnosti. 
Boyce, C. i Neale, P. (2006). Conducting in-depth interviews: A guide for designing and conducting in-depth interviews for evaluation input. Watertown, MA: Pathfinder International Tool Series, Monitoring and Evaluation -2 .

Callens, S. (2010). The EU legal framework on e-health. U E. Mossialos, G. Permanand, R. Baeten i T. Hervey (Ur.), Health systems governance in Europe: The role of European Union law and policy (str. 561-588). Cambridge University Press. doi:10.1017/CBO9780511750496.014

Commission of the European Communities (2004). E-health-making healthcare better for European citizens: An action plan fo a European e-health area. Posjećeno 20. 6. 2011. na: http://eur-lex.europa.eu/LexUriServ/ LexUriServ.do?uri=COM:2004:0356:FIN:EN:PDF

Delegation of the European Union (2011). The EU and eHealth: Good for patients, good for medicine, good for the economy. Posjećeno 20. 6. 2011. na: http://www.eurunion.org/eu/images/stories/euinsight-ehealthfeb2011.pdf

Dey, I. (1993). Qualitative data analysis: A user-friendly guide for social scientists. London: Routlegde.

Dobrev, A., Jones, T., Stroetmann, V. N., Stroetmann, K. A, Artmann, J., Kersting, A., Kasiri, N., Zegners, D. i Lilischkis, S. (2008). Sources of financing and policy recommendations to member states and the European Commission on boosting ehealth investment. Final report. Bruxelles: European Commission.

Economist Intelligence Unit (2011). The future of healthcare in Europe. Posjećeno 1. 9. 2011. na: http://www.eufutureofhealthcare.com/sites/ default/files/EIU-Janssen\%20Healthcare_Web\%20version.pdf

Eisenhardt, K. M. (1989). Building theories from case study research. Academy of Management Review, 14(4), 532-550. doi:10.2307/258557

European Comission (2007). Study on the legal framework for interoperable ehealth in Europe. Final report. Posjećeno 19. 6. 2011. na: http://ec. europa.eu/information_society/activities/health/docs/studies/legalfw-interop/ehealth-legal-fmwk-final-report.pdf

European Commission (2010). Digital Agenda for Europe. Posjećeno 20. 6. 2011. na: http://ec.europa.eu/information_society/digital-agenda/ documents/digital-agenda-communication-en.pdf

Gell, G., Madjaric, M., Leodolter, W., Köle, W. i Leitner, H. (2000). HIS purchase projects in public hospitals of Styria, Austria. International Journal of Medical Informatics, 58-59, 147-155. doi:10.1016/S1386-5056 (00)00083-6

Golafshani, N. (2003). Understanding reliability and validity in qualitative research. The Qualtiative Report, 8(4), 597-607.

Guion, L. A. (2002). Triangulation: Establishing the validity of qualitative studies. University of Florida, FCS6014. Posjećeno 25. 9. 2012. na: http://www.rayman-bacchus.net/uploads/documents/Triangulation.pdf Hein, M. A. (2009). Telemedicine: An important force in the transformation of healthcare. Posjećeno 29. 6. 2011. na: http://www.ehow.com/info_ 8566308_two-other-global-communication-technologies.html 
DRUŠ. ISTRAŽ. ZAGREB GOD. 21 (2012) BR. 4 (118),

STR. $843-862$

OSTOJIĆ, R., BILAS, V., FRANC, S.:

E-ZDRAVSTVO...
Hruška, D. (2010). Donošenje radikalnih odluka u velikim organizacijama. (Neobjavljena doktorska disertacija). Sveučilište u Zagrebu, Ekonomski fakultet.

Hrvatski zavod za telemedicinu. Posjećeno 4. 7. 2011. na: http://www. ztm.hr/ index.php?q=node/27

Jones, T., Dobrev, A., Artman, J. i Stroetmann, V. N. (2007). Conceptual framework, healthcare and e-health investment context and challenges. Report. Bruxelles: European Commission.

Juffernburch, K. (2010). How to make e-health successful. A microeconomic perspective. Cisco group. Posjećeno 20. 6. 2011. na: http://www. cisco.com/web/about/ac79/docs/pov/How_to_Make_eealth_Successf ul_PoV.pdf

Jurković, D. (2011). Informatizacija primarne zdravstvene zaštite - "ordinacija bez papira". Ministarstvo zdravstva i socijalne skrbi. Posjećeno 4. 7. 2011. na: http://www.mzss.hr/content/download/6466/49525/file/INFORMA TIZACIJA_PRIMARNE_ZDRAVSTVENE_ZA\%C5\%A0TITE_ORDI NA CIJA_B_EZ_PAPIRA. $\bar{p} d f$

Kvale, S. (1996). Interviews: An introduction to qualitative research interviewing. Thousands Oaks: Sage Publications.

Mack, N., Woodsong, C., MacQueen, K. M., Guest, G. i Namey, E. (2005). Qualitative research methods: A data collector's field guide. North Carolina: Family Health International.

Mađarić, M. (2009). Predavanja na poslijediplomskom studiju na Medicinskom fakultetu u Zagrebu - Zdravstveni informatički sustavi I i II. Posjećeno 2. 3. 2012. na: http://www.linkedin.com/profile/view? id $=19356792 \&$ trk $=$ tab_pro

Mađarić, M. (2009-2010). Innovation management in healthcare IT. Healthcare IT Management, 4(5), 26-29.

Mađarić, M., Antabak, A., Karlo, R. i Nikolić, H. (2011a). Approach to establishing ChiPSoNet - Children Protection Social Network // Proceedings of Central European Conference on Information and Intelligent Systems, CECiiS 2011 / Aurer, B., Bača, M., Rabuzin, K. (Ur.), Varaždin: Faculty of Organization and Informatics Varaždin.

Mađarić, M. i Nesek-Mađarić, V. (2011b). The role of I. S. in patient-friendly hospital. Regional Conference on SEEeHealth. Ljubljana, Slovenia, 16-18. 2. 2011. Posjećeno 2. 3. 2012. na: http://www.cegd.eu/events/2011/ SEEeHealth/Miroslav\%20Madjaric.pdf

Maxwell, J. A. (2002). Understanding and validity in qualitative research. U: M. A. Huberman i M. B. Miles (Ur.), The qualitative researcher's companion (str. 37-65). Thousands Oaks: Sage Publications.

Miles, M. B. i Huberman, A. M. (1994). Qualitative data analysis. Thousand Oaks: Sage Publications.

Orb, A., Eisenhauer, L. i Wynaden, D. (2001). Ethics in qualitative research. Journal of nursing scholarship, 33(1), 93-96. doi:10.1111/j.15475069.2001.00093.x

Ostojić, R., Bilas, V. i Franc, S. (2012). Stanje i perspektive razvoja zdravstvenih sustava zemalja članica Europske unije i Republike Hrvatske. U tisku.

Pale, P. (1998). Telemedicina. InfoTrend, 1(1), 1-1. 
DRUŠ. ISTRAŽ. ZAGREB GOD. 21 (2012), BR. 4 (118),

STR. 843-862

OSTOJIĆ, R., BILAS, V., FRANC, S.: E-ZDRAVSTVO.
Pejakić, I. (2009). Telemedicina u Republici Hrvatskoj - korisnosti i izazovi. Zbornik radova međunarodne konferencije Upravljanje promjenama u sestrinstvu (str. 101-105), Zagreb: Zdravstveno veleučilište u Zagrebu. Posjećeno 4. 7. 2011. na: http://www.zvu.hr/opatija/2009/zbornik/ zbornik.pdf

Rabiee, F. (2004). Focus-group interview and data analysis. Proceedings of the Nutrition Society, 63(4), 655-660. doi:10.1079/PNS2004399

Rodrigues, R. J. (2003). Opportunities and challenges in deployment of global e-health. International Journal of Healthcare Technology and Management, 5(3/4/5), 335-358. doi:10.1504/IJHTM.2003.004173

Saunders, M., Lewis, P. i Thornhill, A. (2007). Research methods for business students. Prentice Hall, Pearson Education Limited.

Spencer, L., Ritchie, J. i O'Connor, W. (2003). Analysis: Practices, principles and processes. U J. Ritchie i J. Lewis (Ur.), Qualitative research practice: A guide for social science students (str. 199-219). Thousand Oaks: Sage Publications.

Stenius, K., Mäkelä, K., Miovsky, M. i Gabrhelik, R. (2008). How to write publishable qualitative research? U T. F. Babor, K. Stenius, S. Savva i J. O'Reilly (Ur.), Publishing addiction science: A guide for the perplexed (str. 82-97). World Health Organization i International Society of Addiction Journal Editors.

Stroetmann, K., Artmann, J., Stroetmann, V. N., Protti, D., Dumortier, J., Giest, S., Walossek, U. i Whitehouse, D. (2011). European countries on their journey towards national eHealth infrastructures. Final European progress report. Bruxelles: European Commission.

WCAG. Posjećeno 2. 3. 2012. na http://www.w3.org/TR/WCAG/

White, C., Woodfield, K. i Ritchie, J. (2003). Reporting and presenting qualitative data. U J. Ritchie i J. Lewis (Ur.), Qualitative research practice: A guide for social science students (str. 287-321). Thousands Oaks: Sage Publications.

\section{E-Health - Improvement of the Health Care System through the Application of Information and Communication Technology}

\section{Rajko OSTOJIĆ}

School of Medicine, Zagreb

Vlatka BILAS, Sanja FRANC

Faculty of Economics and Business, Zagreb

Concern about health is a continuous necessity, and in modern living conditions information and communication technology enables faster and simpler access to health care and overcomes the gap between spatial and time distance, which simplifies provision of services. There is great potential for e-health in the future, it is even likely to become an 
DRUŠ. ISTRAŽ. ZAGREB GOD. 21 (2012)

BR. $4(118)$

STR. 843-862

OSTOJIĆ, R., BILAS, V., FRANC, S.:

E-ZDRÁVSTVO. imperative of modern society. A well organized and efficient health care system that promotes innovation in areas such as e-health brings benefits for individuals, society and the economy as a whole. In this paper, advantages, disadvantages and obstacles to the use of e-health are determined in the case of EU countries and the Republic of Croatia, with focus on the potential of e-health to improve the health care system. A qualitative research was conducted in the form of semi-structured interviews with 49 participants in the Republic of Croatia from June to October 2011. In Croatia there are several different models of health informatization and this diminishes both the transparency and efficiency of the whole process as well as undermines e-health benefits for health and health care system improvement. Factors are described that influence the success of e-health implementation and delivery, ultimately enabling the development of a systematic, successful and sustainable e-health development strategy in Croatia.

Keywords: e-health, European Union, Republic of Croatia 